\title{
Effect of ethanolic extract of the leaves of plant Annona squamosa on hematological and biochemical parameters in normal rats
}

\author{
Preeti Singh, Veena Batra Kushwaha
}

\author{
Department of Zoology, D.D.U. Gorakhpur University, Gorakhpur, India
}

\begin{abstract}
The present study was designed to elucidate the effects of ethanolic extract of leaves of Annona squamosa L. (Annonaceae) on hematological and biochemical indices in normal rat. The male rats were gavaged ethanolic extract of Annona squamosa leaves at the dose level of 200 and 300 $\mathrm{mg} / \mathrm{Kg}$ body weight/rat/day for 28 days. A significant decrease in hematological indices like hemoglobin, $R B C$ count and increase in WBC count, serum parameter like serum cholesterol, serum GPT and GOT was observed.
\end{abstract}

Keywords-Annona squamosa, rat, leaves, Hematological parameters, serum GOT, serum GPT, serum cholesterol.

\section{INTRODUCTION}

Annona squamosa Linn.belonging to family Annonaceae is commonly known as "Custard apple" and is a native of West Indies and South America and is cultivated throughout India, mainly for its edible fruits (Morton, 1987). The leaves of this plant have been used as insecticide, styptic, suppurant and dried fruit works as antidysentric and vermifuge. This plant also possesses anti-fertility, antitumour and anti-diabetic activities in mice and rats. (Gajalakshmi et. al.; 2011, Gupta et.al.; 2005 ; Jain and Dixit (1982);). The present study was undertaken to evaluate the effect ethanolic extract of the leaves of Annona squamosa in normal rats.

\section{MATERIALS AND METHODS}

Plant material and extract preparation: The fresh fruits of Annona squamosa were collected from Gorakhpur district of U.P. (India) and were identified in the department of Botany, University of Gorakhpur. The leaves were removed from stem and were shade dried. The leaves were then powdered and mixed with $100 \%$ ethanol. The extract was then filtered and oven-dried.

Animal model and experimental procedure: Healthy colony bred male albino rats weighting 120-150 grams were used for the experiments. The animals were housed in polypropylene cages and maintained under standard conditions (12h light / 12h dark cycles). Rats were fed with standard www.ijeab.com diet and water was provided ad libitum. The animals were divided into three groups of one control and two treated, each with 16 animals. In treated groups one group received the extract at the dose level of $200 \mathrm{mg} / \mathrm{Kg}$ body weight/rat/day and another group received the extract at the dose level of $300 \mathrm{mg} / \mathrm{Kg}$ body weight/rat/day while the control group was received same amount of vehicle (ethanol). The plant extract was dissolved in ethanol and administered orally to animals every morning for 7, 14, 21 and 28 days respectively. After every $7^{\text {th }}, 14^{\text {th }}, 21^{\text {st }}$ and $28^{\text {th }}$ days both control and treated groups were autopsied under light chloroform anesthesia.

Autopsy schedule: Four animals of each three groups were autopsied for every $7^{\text {th }}, 14^{\text {th }}, 21^{\text {st }}$ and $28^{\text {th }}$ day. Blood was being collected through cardiac puncture.

Blood and serum analysis: The blood of the experimental rats was analyzed for R.B.C and W.B.C count, hemoglobin, serum cholesterol, serum GPT, serum GOT.

Statistical analysis: The results are expressed as mean $\pm \mathrm{SE}$ followed by student's t-test.

\section{RESULTS}

A non-significant decrease in hemoglobin concentration after 7 and 14 day, and a significant $(\mathrm{p}<0.05)$ decrease after 21 and 28 day in rats on exposure to $200 \mathrm{mg} / \mathrm{kg}$ body weight of extract and a significant $(\mathrm{p}<0.05)$ decrease in hemoglobin concentration was observed on exposure to 300 $\mathrm{mg} / \mathrm{kg}$ body weight was observed in comparison to control rats.

A non-significant decrease in $\mathrm{RBC}$ count of treated rats was observed on exposure to $200 \mathrm{mg} / \mathrm{kg}$ body weight of extract and while a non significant decrease after 7 days and a significant $(\mathrm{p}<0.05)$ decrease in was observed after 14, 21 and 28 days on exposure to $300 \mathrm{mg} / \mathrm{kg}$ body weight of extract in rats in comparison to control.

A significant $(\mathrm{p}<0.05)$ increase in WBC count of rats in comparison to control was observed on exposure to both the doses of extract. 
Two-way ANOVA test indicates that variation in the strength of dose and exposure time, significantly influence the hemoglobin concentration, RBC count and WBC count of rats (Table 1).

Blood biochemistry

A significant $(\mathrm{p}<0.05)$ decrease in blood glucose, increase in serum cholesterol, serum GOT and serum GPT in rats exposed to both the doses of extract was recorded in comparison to control rats.

Two-way ANOVA test indicates that variation in the strength of dose and exposure time, significantly $(\mathrm{p}<0.01)$ influence the blood glucose, serum cholesterol, serum GOT and serum GPT of rats exposed to the extract (Table 2).

Table.1: Effect of ethanolic extract of the leaves of plant Annona squamosa on hematological parameters in normal rats

\begin{tabular}{|c|c|c|c|c|c|c|}
\hline \multirow[t]{2}{*}{ Parameters } & \multirow[t]{2}{*}{ Days } & \multirow{2}{*}{$\begin{array}{l}\text { Control } \\
\text { Rats } \\
\text { Mean } \pm \text { SE }\end{array}$} & \multicolumn{2}{|c|}{ Treated rats } & \multicolumn{2}{|c|}{ Change in \% } \\
\hline & & & $\begin{array}{l}\text { 200mg/kg } \\
\text { Body } \\
\text { Weight } \\
\text { Mean } \pm \text { SE }\end{array}$ & $\begin{array}{l}\text { 300mg/kg } \\
\text { Body } \\
\text { Weight } \\
\text { Mean } \pm \text { SE }\end{array}$ & $\begin{array}{c}200 \mathrm{mg} / \mathrm{kg} \\
\text { Body } \\
\text { Weight } \\
\text { Mean }\end{array}$ & $\begin{array}{c}300 \mathrm{mg} / \mathrm{kg} \\
\text { Body } \\
\text { Weight } \\
\text { Mean }\end{array}$ \\
\hline \multirow{4}{*}{$\begin{array}{l}\text { Hemoglobin } \\
(\mathrm{gm} \%)\end{array}$} & 7 & $\begin{array}{l}14.46 \\
\pm 0.17\end{array}$ & $\begin{array}{l}11.97^{*} \\
\pm 0.12\end{array}$ & $\begin{array}{l}11.78 * \\
\pm 0.014\end{array}$ & $17.21 \downarrow$ & $18.53 \downarrow$ \\
\hline & 14 & $\begin{array}{l}14.75 \\
\pm 0.08\end{array}$ & $\begin{array}{l}11.70 * \\
\pm 0.13\end{array}$ & $\begin{array}{l}11.63^{*} \\
\pm 0.18\end{array}$ & $20.68 \downarrow$ & $21.15 \downarrow$ \\
\hline & 21 & $\begin{array}{l}14.83 \\
\pm 0.06\end{array}$ & $\begin{array}{l}11.54 * \\
\pm 0.08\end{array}$ & $\begin{array}{l}10.86 * \\
\pm 0.20\end{array}$ & $22.18 \downarrow$ & $26.77 \downarrow$ \\
\hline & 28 & $\begin{array}{l}14.88 \\
\pm 0.04\end{array}$ & $\begin{array}{l}11.37 * * \\
\pm 0.08\end{array}$ & $\begin{array}{l}10.34^{*} \\
\pm 0.18\end{array}$ & $23.59 \downarrow$ & $31.66 \downarrow$ \\
\hline \multirow{4}{*}{$\begin{array}{l}\text { RBC count } \\
\text { (million/cumm) }\end{array}$} & 7 & $\begin{array}{l}8.68 \\
\pm 0.09\end{array}$ & $\begin{array}{l}8.52 * \\
\pm 0.12\end{array}$ & $\begin{array}{l}8.35^{*} \\
\pm 0.09\end{array}$ & $1.84 \downarrow$ & $3.80 \downarrow$ \\
\hline & 14 & $\begin{array}{l}8.83 \\
\pm 0.06\end{array}$ & $\begin{array}{l}8.47 * \\
\pm 0.12\end{array}$ & $\begin{array}{l}8.27 * \\
\pm 0.07\end{array}$ & $4.08 \downarrow$ & $6.34 \downarrow$ \\
\hline & 21 & $\begin{array}{l}9.20 \\
\pm 0.19\end{array}$ & $\begin{array}{l}8.31 * \\
\pm 0.11\end{array}$ & $\begin{array}{l}7.68 * \\
\pm 0.08\end{array}$ & $9.67 \downarrow$ & $16.52 \downarrow$ \\
\hline & 28 & $\begin{array}{l}9.60 \\
\pm 0.19 \\
\end{array}$ & $\begin{array}{l}8.14^{*} \\
\pm 0.09\end{array}$ & $\begin{array}{l}7.46^{*} \\
\pm 0.2\end{array}$ & $15.20 \downarrow$ & $22.29 \downarrow$ \\
\hline \multirow{4}{*}{$\begin{array}{l}\text { WBC count } \\
\text { (thousand/cumm) }\end{array}$} & 7 & $\begin{array}{l}8.61 \\
\pm 0.04\end{array}$ & $\begin{array}{l}8.8^{*} \\
\pm 0.06\end{array}$ & $\begin{array}{l}10.68 * \\
\pm 0.14\end{array}$ & $2.2 \uparrow$ & $24.04 \uparrow$ \\
\hline & 14 & $\begin{array}{l}8.52 \\
\pm 0.07\end{array}$ & $\begin{array}{l}9.5^{*} \\
\pm 0.10\end{array}$ & $\begin{array}{l}11.38 * \\
\pm 0.34\end{array}$ & $11.50 \uparrow$ & $33.57 \uparrow$ \\
\hline & 21 & $\begin{array}{l}8.87 \\
\pm 0.01\end{array}$ & $\begin{array}{l}10.01 * \\
\pm 0.20\end{array}$ & $\begin{array}{l}11.97 * \\
\pm 0.17\end{array}$ & $12.85 \uparrow$ & $34.94 \uparrow$ \\
\hline & 28 & $\begin{array}{l}8.59 \\
\pm 0.04\end{array}$ & $\begin{array}{l}10.49 * \\
\pm 0.30\end{array}$ & $\begin{array}{l}12.81 * \\
\pm 0.08\end{array}$ & $22.11 \uparrow$ & $49.12 \uparrow$ \\
\hline
\end{tabular}

*Indicates significant $(\mathrm{p}<0.05)$ and $* *$ indicates significant $(\mathrm{p}<0.01)$. 
Table.2: Effect of ethanolic extract of the leaves of plant Annona squamosa on blood biochemical parameters in normal rats.

\begin{tabular}{|c|c|c|c|c|c|c|}
\hline \multirow[t]{2}{*}{ Parameters } & \multirow[t]{2}{*}{ Days } & \multirow{2}{*}{$\begin{array}{l}\text { Control } \\
\text { Rats } \\
\text { Mean } \pm \text { SE }\end{array}$} & \multicolumn{2}{|c|}{ Treated rats } & \multicolumn{2}{|c|}{ Change in $\%$} \\
\hline & & & $\begin{array}{l}\text { 200mg/kg } \\
\text { Body } \\
\text { Weight } \\
\text { Mean } \pm \text { SE }\end{array}$ & $\begin{array}{l}\text { 300mg/kg } \\
\text { Body } \\
\text { Weight } \\
\text { Mean } \pm \text { SE }\end{array}$ & $\begin{array}{c}\text { 200mg/kg } \\
\text { Body } \\
\text { Weight } \\
\text { Mean }\end{array}$ & $\begin{array}{c}\text { 300mg/kg } \\
\text { Body } \\
\text { Weight } \\
\text { Mean }\end{array}$ \\
\hline \multirow{4}{*}{ Blood Glucose } & 7 & $\begin{array}{l}118.69 \\
\pm 0.52\end{array}$ & $111.72 * \pm 0.31$ & $103.99 \pm 0.63$ & $94.13 \downarrow$ & $87.62 \downarrow$ \\
\hline & 14 & $\begin{array}{l}120.91 \\
\pm 0.35\end{array}$ & $111.03 * \pm 0.52$ & $99.82 * \pm 0.35$ & $91.83 \downarrow$ & $82.56 \downarrow$ \\
\hline & 21 & $\begin{array}{l}121.72 \\
\pm 0.43\end{array}$ & $108.53^{*} \pm 0.49$ & $96.92 * \pm 0.87$ & $89.17 \downarrow$ & $79.63 \downarrow$ \\
\hline & 28 & $\begin{array}{l}124.11 \\
\pm 0.66\end{array}$ & $106.88^{*} \pm 0.13$ & $94.24 * \pm 0.48$ & $86.12 \downarrow$ & $75.94 \downarrow$ \\
\hline \multirow{4}{*}{$\begin{array}{l}\text { Serum } \\
\text { cholesterol }\end{array}$} & 7 & $\begin{array}{l}58.47 \\
\pm 0.16\end{array}$ & $\begin{array}{l}62.89^{*} \\
\pm 0.38\end{array}$ & $\begin{array}{l}65.35^{*} \\
\pm 0.16\end{array}$ & $7.56 \uparrow$ & $11.76 \uparrow$ \\
\hline & 14 & $59.37 \pm 0.07$ & $\begin{array}{l}63.92^{*} \\
\pm 0.14\end{array}$ & $\begin{array}{l}67.10^{*} \\
\pm 0.26\end{array}$ & $7.66 \uparrow$ & $13.02 \uparrow$ \\
\hline & 21 & $\begin{array}{l}60.16 \\
\pm 0.31\end{array}$ & $\begin{array}{l}64.63^{*} \\
\pm 0.29\end{array}$ & $\begin{array}{l}69.51 \\
\pm 0.14 *\end{array}$ & $7.43 \uparrow$ & $15.54 \uparrow$ \\
\hline & 28 & $\begin{array}{l}61.60 \\
\pm 0.36\end{array}$ & $\begin{array}{l}65.99 * \\
\pm 0.32\end{array}$ & $\begin{array}{l}72.55^{* *} \\
\pm 0.12\end{array}$ & $7.12 \uparrow$ & $17.77 \uparrow$ \\
\hline \multirow[t]{4}{*}{ Serum GOT } & 7 & $\begin{array}{l}84.03 \\
\pm 0.19\end{array}$ & $\begin{array}{l}90.25 * * \\
\pm 0.07\end{array}$ & $\begin{array}{l}104.12^{*} \\
\pm 0.29\end{array}$ & $7.4 \uparrow$ & $23.90 \uparrow$ \\
\hline & 14 & $\begin{array}{l}85.04 \\
\pm 0.08\end{array}$ & $\begin{array}{l}94.54 * \\
\pm 1.13\end{array}$ & $\begin{array}{l}110.47^{*} \\
\pm 0.08\end{array}$ & $11.17 \uparrow$ & $29.90 \uparrow$ \\
\hline & 21 & $\begin{array}{l}85.75 \\
\pm 0.06\end{array}$ & $\begin{array}{l}95.34^{*} \\
\pm 0.12\end{array}$ & $\begin{array}{l}115.30^{*} \\
\pm 0.05\end{array}$ & $11.18 \uparrow$ & $34.46 \uparrow$ \\
\hline & 28 & $\begin{array}{l}87.52 \\
\pm 0.13\end{array}$ & $\begin{array}{l}98.48^{*} \\
\pm 0.12\end{array}$ & $\begin{array}{l}121.48^{*} \\
\pm 0.14\end{array}$ & $12.78 \uparrow$ & $38.80 \uparrow$ \\
\hline \multirow[t]{4}{*}{ Serum GPT } & 7 & $\begin{array}{l}54.74 \\
\pm 0.55\end{array}$ & $\begin{array}{l}67.67 * \\
\pm 6.23\end{array}$ & $\begin{array}{l}75.25^{*} \\
\pm 0.03\end{array}$ & $23.62 \uparrow$ & $37.47 \uparrow$ \\
\hline & 14 & $\begin{array}{l}56.67 \\
\pm 0.48\end{array}$ & $\begin{array}{l}73.32 * \\
\pm 0.10\end{array}$ & $\begin{array}{l}78.67^{*} \\
\pm 0.34\end{array}$ & $29.38 \uparrow$ & $38.82 \uparrow$ \\
\hline & 21 & $\begin{array}{l}59.85 \\
\pm 0.34\end{array}$ & $\begin{array}{l}83.77 \text { ** } \\
\pm 1.06\end{array}$ & $\begin{array}{l}88.59^{*} \\
\pm 0.87\end{array}$ & $39.97 \uparrow$ & $48.02 \uparrow$ \\
\hline & 28 & $\begin{array}{l}62.98 \\
\pm 0.25\end{array}$ & $\begin{array}{l}90.36^{*} \\
\pm 0.14\end{array}$ & $\begin{array}{l}102.6^{*} \\
\pm 1.5\end{array}$ & $43.47 \uparrow$ & $62.91 \uparrow$ \\
\hline
\end{tabular}

*Indicates significant $(\mathrm{p}<0.05)$ and $* *$ indicates significant $(\mathrm{p}<0.01)$.

\section{DISCUSSION}

Haematological indices like haemoglobin content, blood cell counts (RBC and WBC) revealed significant changes due to the treatment. This reveals the toxic nature of the extract. A significant decrease in erythrocyte (RBC) count and haemoglobin percent was observed and this can be attributed to defective haemopoisis (Maurya and Kushwaha, 2010, Choudhary and Deshmukh, 2007). The decrease in haemoglobin content and RBC count can be correlated with www.ijjeab.com paling of the animals, weakness and morbidity. (Cella,et al., 2000; Kumar, et al., 1999; Choudhari and Deshmukh, 2007).Significant increase in WBC count of treated rats was observed in the present study can be attributed to the stimulation of immune system (Oluwole, 2001). An increase in the WBC count has been reported after chemical stress by various workers (Pandey, et.al., 1976; Goel and Garg, 1980; Sastry and Sharma, 1980). A significant increase in the activity of SGPT and SGOT of treated rats 
was observed in the present study. Excess of SGOT is common in myocardial infraction (Varley, 1976). The altered levels of these enzymes are found to be affected by the physiological status of the important organs as evidenced by the alteration in transaminase activity levels that leads to an increase in transamination process required during depletion of body proteins. Arora and Saxena (1999), Oser (1965), Ayub Shah and Gupta (2001) have reported that an increase in SGOT and SGPT in albino rats, after administration of synthetic pyrethroid for 21 days, causes change in membrane permeability and hepatocyte dysfunction. An increase in blood cholesterol level of rats on exposure to the extract in the present study may be due to the accumulation of cholesterol as it is associated with retarded oxidative breakdown of sugar under stressed condition (Kabeer, et al., 1978).

\section{ACKNOWLEDGEMENT}

This research work is supported by the University Grant Commission (UGC), New Delhi. Vide letter F. No. 37131/2009(SR) dated 12 Dec 2009.

\section{REFERENCES}

[1] Arora, S. and Saxena, P.N. (1999). Decis (synthetic Pyrethroid) induced serum biochemical alterations in Rattus norvegicus. Proc. Acad. Environ. Biol. 8(suppl), 33(0129,c).

[2] Ayub Shah, M.A. and Gupta, P.K. (2001). Sub acute toxicity studies on peremethrin a synthetic pyrethroid insecticide with particular reference to biochemical changes in rats. Indian J. Toxicol. 8, 61-67.

[3] Choudhary, C.V. and Deshmukh, P.B. (2007). Acute and subchronic toxicity study of somecarpus anacardium on haemoglobin percent and RBC count of male albino rats. Journal of Herbal Medicine and Toxicology, 1(1): 43-45.

[4] Gajalakshmi, S., Divya, R., Divya Deepika, V., Mythili, S. and Sathiavelu, A., (2011). Pharmacological activities of Annona squamosa; A review, Int. J. Pharma. Sci. Rev. Res., 10(2), 24-29.

[5] Goel, K.A. and Garg, V. (1980). 2, 4-diamino, 3amino azobenzene 'DAAB' induced haematobiochemical anomalies in channa punctatus. Bulls. Environ. Contam. Toxicol., 25, 469-476.

[6] Gupta RK, Kesari AN, Murthy PS, Chandra R, Tandon V and Watal G, (2005), Hypoglycaemic and antidiabetic effect of ethanolic extract of leaves of Annona squamosa in experimental animals, J Ethnopharmacol, 99(1), 75-81.
[7] Jain, G.C. and Dixit, V.P. (1982). Effect of Annona squamosa EtOH extract and testicular extract and testicular function of dogs (Canis indicus). II Annual session of science, Abst- 15 Bhavnagar, pp.22.

[8] Kabeer, A.I., Begum, M.D., Sivias, S. and Pumanarao, K.V. (1978). Effect of malathion on free amino acids, total protein, glycogen and some enzymes of plecypod, Lamellidens marginalis (Lamark). Proc. Ind. Aca. Sci. 87(12): 377-387.

[9] Maurya, S. and Kushwaha, V.B., (2010). Effect of ethanolic extract of Parthenium hysterophorus on haematological parameters in rats, The Bioscan, 5(3), 437-440.

[10] Mortan, J., Sugar Apple. In: J. Morton (Ed), Fruits of warm climate: Miami. Greensboro, Media, pp. 69-72.

[11] Oluwole, F.S. (2001). Effect of garlic on some haematological and biochemical parameters. Afr. J. Biomed. (2001): Vol 4; 139-141.

[12] Oser, B.L. (1965). Hawk's Physiological Chemistry, $14^{\text {th }}$ edn. Mc Gee Hill Book Co., N.Y.

[13] Pandey, B.N., Chandal, A.K. and Singh, M.P. (1976). Effect of malathion on oxygen consumption and blood of channa punctatus (Bloch). The indian J. Zool. 17 (2), 95-100.

[14] Sastry, K.V. and Sharma, K. (1980). Mercury induced haematological and biochemical anomalies in ophiocephalus (channa) punctatus. Toxicol. Lett. 5, 245-249.

[15] Varely, H. (1976). Practical clinical biochemistry, $4^{\text {th }}$ edn. Arnold Helnmann Publisher, Indian Paul's Press. New Delhi. 